\title{
Marsh development and sea level changes in the Gernika Estuary (southern Bay of Biscay): foraminifers as tidal indicators
}

\author{
ANA PASCUAL and JULIO RODRIGUEZ-LAZARO \\ Universidad del País Vasco/E.H.U. Facultad de Ciencia y Tecnología, Departamento de Estratigrafía y Paleontología, \\ Apartado 644, 48080 Bilbao, Spain. E-mail: julio.rodriguez@ehu.es
}

\begin{abstract}
SUMMARY: The ecological distribution of some species of Foraminifera living in estuaries can be used in the interpretation of former coastal lines. There is a close relationship between tide level and the distribution of particular benthic foraminifer species. A characterisation of tide levels based on the benthic foraminifers in four cores from this estuary allowed us to interpret the changes over time in transitional environments during the modern Holocene. The estuary was filled during the last 6500 years following a general accretional model. Marshes have existed in this area for about 4600 years. This model is described for the first time in the area, based on benthic foraminiferal zones. These zones define a general emergence sequence, interrupted by a transgressive marine pulsation. We describe the evolution of marsh sub-environments in relation to the sea-level changes, materialised by a transgressive pulsation which shows an interruption in the accretional process dated $1910 \pm 50 \mathrm{BP}$
\end{abstract}

Keywords: foraminifers, palaeoenvironmental evolution, Holocene, Gernika estuary, southern Bay of Biscay.

RESUMEN: EVOLUCIÓN DE UNA MARISMA Y CAMBIOS DEL NIVEL DEL MAR EN El ESTUARIO DE GERNIKA (SUR DEL GOLFO DE VIZCAYA): LOS FORAMINÍFEROS COMO INDICADORES DE MAREAS. - La distribución ecológica de algunas especies de foraminíferos que viven en estuarios pueden ser utilizadas en la interpretación de antiguas líneas de costa. Existe una clara relación entre el nivel mareal y la distribución de especies concretas de foraminíferos bentónicos. La caracterización de estos niveles de mareas basados en los foraminíferos bentónicos en cuatro sondeos de este estuario, permite interpretar los cambios en estos ambientes transicionales durante el Holoceno. El estuario ha sido rellenado durante los últimos 6500 años, siguiendo un modelo general acrecional. Las marismas han existido en esta área desde hace unos 4600 años. Este modelo describe la evolución de los subambientes de marisma, en relación con cambios en el nivel del mar, materializado por una pulsación transgresiva que evidencia una interrupción en el proceso acrecional, datada de $1910 \pm 50 \mathrm{BP}$.

Palabras clave: foraminíferos, evolución paleoambiental, Holoceno, estuario de Gernika, sur Golfo de Vizcaya.

\section{INTRODUCTION}

The Urdaibai region in N Spain was declared a protected area by the "Man and Biosphere Committee" (MAB) of UNESCO in 1984. The estuary of Gernika, as a part of Urdaibai, is recognised as a "Corine Biotope", and since 1993 has been considered a wetland of international importance. It is on the Ramsar List. The whole estuary is also included in a catalogue of "Areas of National
Importance for Birds" in Europe. Nevertheless, the salt marshes of Urdaibai were extensively reclaimed during the phase of agricultural expansion in the late $18^{\text {th }}$ century. As cultivation was extended, the malaria that formerly ravaged this region was eliminated (Meaza and Ugarte, 1988). Thus, 500 hectares of salt marshes in the reserve of Urdaibai have been reclaimed over time.

Estuaries develop in the transition zone between land and marine areas. Their shape and size are 
altered continuously by the erosion and deposition of sediments, and by changes in sea level. After the last ice age when the fluvial valleys eroded and the subsequent transgressive episode, a great amount of marine, continental and estuarine sediments were deposited in estuaries. These sediments are very rich in paleontological remains, particularly benthic foraminifers and ostracods. These microfossils have been extensively used in palaeogeographic and palaeoenvironmental reconstructions, due to their sensitivity to changes in the parameters controlling the environment: salinity, temperature, substratum, oxygen and depth (Murray, 1991; Bosence and Allison, 1995). Vertical analyses of these sediments provides information on palaeoenvironmental changes, including sea level oscillations.

In support of archaeological studies in this area, we studied the changes over time in the environment of the salt marshes of Urdaibai during the late Holocene, based on the lithology and the benthic foraminifer assemblages of four sediment cores drilled in this estuary. The aim of this work is to interpret the sedimentary sequence of the salt marshes of Urdaibai, to characterise changes in palaeoenvironments contemporary with the human occupation, and to establish the chronology of those changes.

In this work we studied the sedimentology and the micropaleontology of four cores drilled in the upper, middle and lower parts of the estuary, now located on reclaimed areas far from the active channel. The location of the cores was established on the basis of several criteria, in particular the proximity of several archaeological sites.

\section{Background to the study}

Early studies of foraminifers from the Gernika estuary were aimed at learning the biocenosis composition, ecology and distribution of estuarine species, and pinpointing the importance of the main environmental factors responsible for microfaunal structure. Based upon foraminifer assemblages, two main zones have been recognised in this estuary (Pascual et al., 1991; Pascual, 1992): (1) a silty upper estuary with a salinity of between 1 and 32 and a foraminifer assemblage dominated by Ammonia tepida, Haynesina germanica and Cribroelphidium williamsonii, and (2) a sandy lower estuary with marine characteristics $(\mathrm{S}=32-34)$ and an assemblage dominated by Lobatula lobatula (as
Cibicides lobatulus), Quinqueloculina seminula and Elphidium crispum.

More recent studies have dealt with Quaternary palaeoecology based on foraminifers in the Gernika estuary, the application of geochemical methods to the calculation of the filling of the estuary from the late Holocene (Pascual et al., 1998), and the use of foraminifers as pollution indicators (Pascual et al., 2002).

\section{Study site}

The Gernika estuary belongs to the Urdaibai hydrographic basin, located in the southern Bay of Biscay. The estuary is about $10.6 \mathrm{~km}$ in length and less than $1 \mathrm{~km}$ in width (Fig. 1). It is oriented S-N and is geologically located on an anticline fold with faulted hinge, with plastic rocks of the Triassic Keuper outcrop. The Oka River is cut into these rocks and was invaded during the Holocene transgression. The active channel has an average depth of $2.6 \mathrm{~m}$, though it can reach $4 \mathrm{~m}$ near the lower end of the estuary during the maximum tidal oscillation. The estuary runs through the town of Gernika, where it is possible to follow the tidal influence.

The estuary has two different areas: (1) the upper estuary, which is formed by marshland with siltyclayey sediment colonised by Spartina maritima, Phragmites australis, Salicornia ramosissima, Puccinellia maritima, Halimione portulacoides and Suaeda maritima (Benito and Onaindia, 1991), and

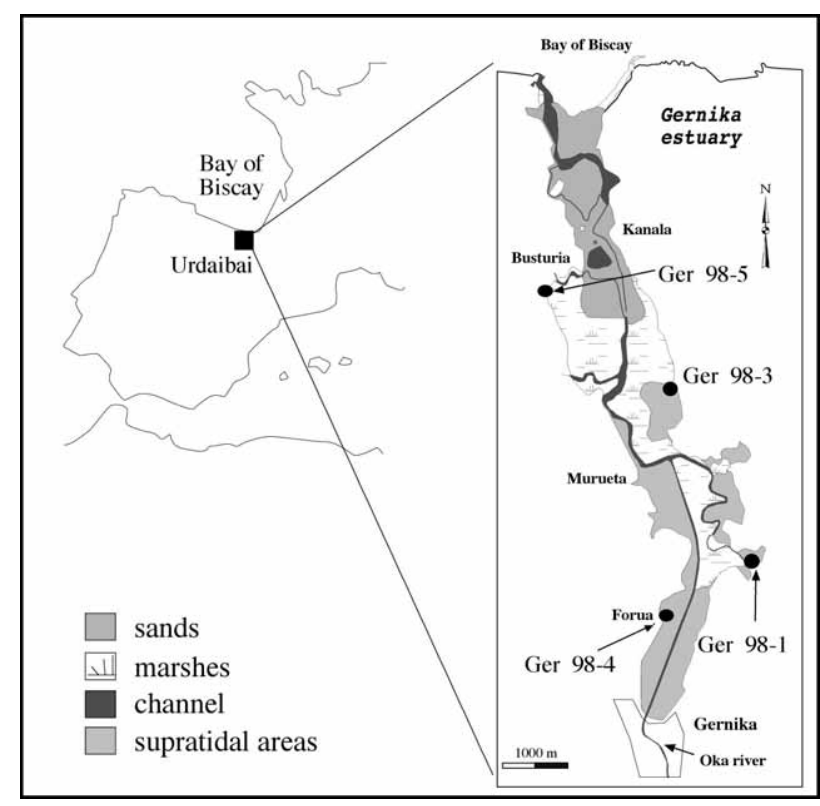

FIG. 1. - Location of the cores studied in the estuary of Gernika. 
(2) the lower estuary, which is composed of sands deposited on the channel banks and the beaches of the borders (Pascual, 1992). The boundary between the two zones is located along the Busturia-Kanala line (see Fig. 1). When the tide ebbs, this area is flooded and a great amount of water is retained; when it flows seawards, it produces strong currents that mobilise the sediment. The water in Kanala flows seawards until two and half hour after the tide has started rising at the mouth of the estuary.

\section{METHODS}

The lithology and micropaleontological content of four cores obtained in Urdaibai by a Kullenberg sampler are analysed in this work. Samples were taken every 10 to $20 \mathrm{~cm}$, and completed in intervals with lithological and/or micropaleontological changes. Samples were washed and sieved (>63 $\mu \mathrm{m})$ and at least 300 individuals of benthic foraminifers were picked out; counting was completed for planktonic foraminifers in samples where they appeared. In less rich samples, foraminifer tests and ostracod carapaces were concentrated by flotation in trichloroetylene. Taxonomic analyses are based on the Loeblich and Tappan (1988) classification. Microfaunal calculations are made as $\mathrm{S}$ (species richness, number of species per sample) and $\alpha$ index (ratio between number of individuals and species per sample) (Fisher et al., 1943); for this index we used the plot of Murray (1973). The sedimentological study of 2693 samples from cores considers the lithology, texture, sedimentary structures, colour and macrofauna. These studies are supplemented by five absolute radiocarbon $\left({ }^{14} \mathrm{C}\right)$ datings from mollusc shells and foraminifers performed by AMS (Accelerator Mass Spectrometry) at Beta Analytic Inc. in Florida (USA).

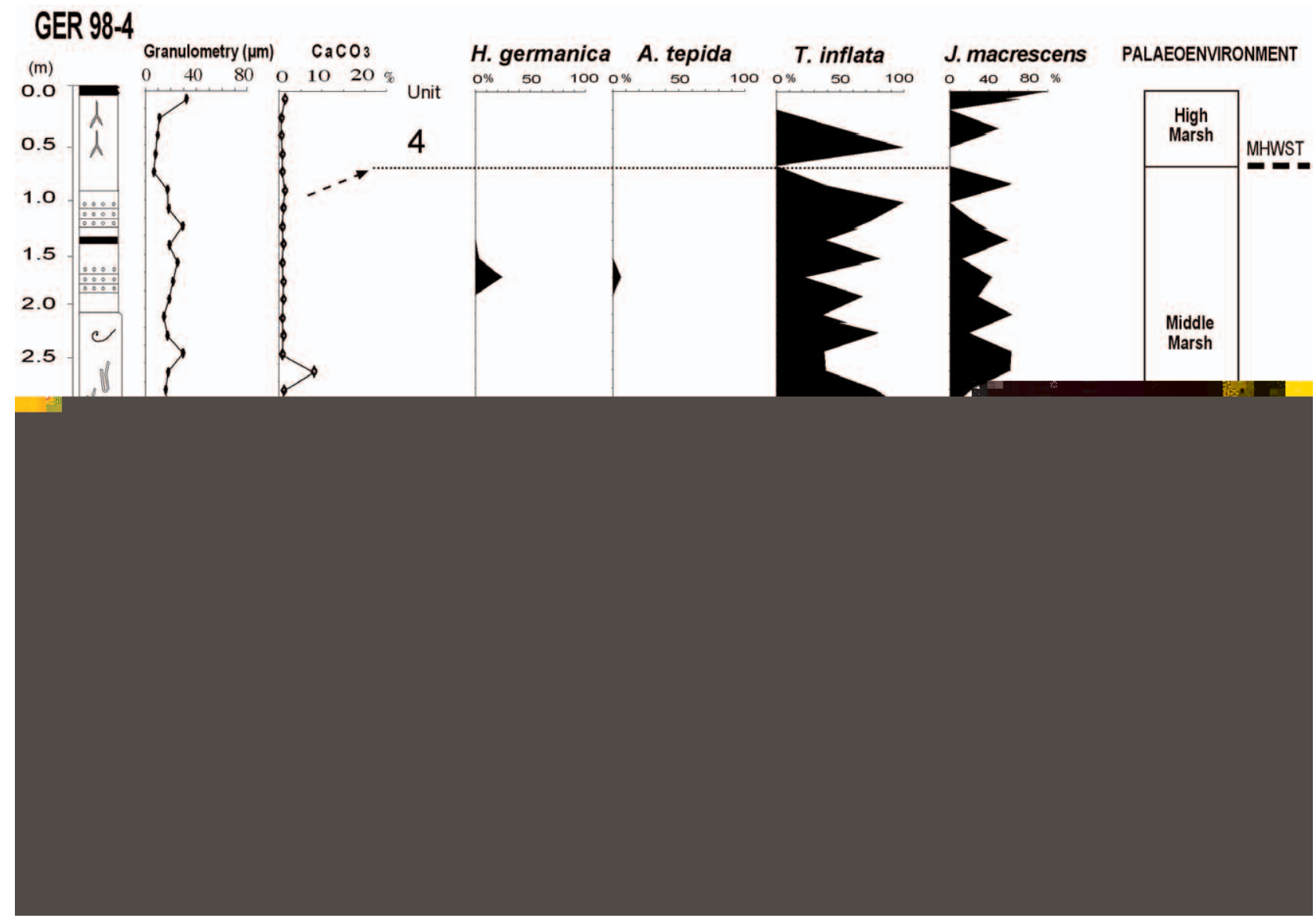

FIG. 2. - Stratigraphy of core GER 98-4. Lithological log, sediment mean grain size, carbonate content and distribution of benthic foraminifer index species are shown. The palaeoenvironmental interpretation of estuarine subenvironments, based on the zonal species, is depicted at the right of the figure. MHWNT, mean high water neap tides; MHW, mean high waters (marked by strong dashed line); MHWST, mean high water spring tides; HAT, highest astronomical tides. The large dashed lines on the right indicate levels of mean tides in the region, as per data from Figure 6. 


\section{RESULTS}

\section{Core GER 98-4}

This core, $7.26 \mathrm{~m}$ long, was drilled in the upper estuary $\left(43^{\circ} 20.4^{\prime} \mathrm{N}, 2^{\circ} 40^{\prime} \mathrm{W}\right)$, on the holocene marsh, $3.75 \mathrm{~m}$ above the local modern mean sea level and about $100 \mathrm{~m}$ from the channel (Fig. 1). The area studied has now been transformed into a high marsh, particularly since the excavation of channels in the estuary between Murueta and Gernika in 1923; it was given over to meadows and cultivation until the 1960s (Benito and Onaindia, 1991). Today much of this land has been abandoned and colonised by Elymus pycnanthus and Juncus maritimus. The sediment is composed of a fine (mud-argillaceous) through the core, with an average of $18 \mu \mathrm{m}$, and a range of variation of 7 to 40 $\mu \mathrm{m}$. A total of 43 samples were studied from this core. The micropalaeontological study included 5694 specimens of foraminifers, which are grouped into 34 species. Based on sedimentological and micropalaeontological characteristics, four units can be distinguished (Fig. 2):

TABLE 1. - Microfaunal (benthic foraminifer) index database of core GER 98-4. The number of individuals, richness and species diversity indices, planktonic foraminifer and test composition percentages are shown. Species distribution is shown only for the four species used in this work. H.ger.: Haynesina germanica; A.tep.: Ammonia tepida; T. inf.: Trochammina inflata; J. mac.: Jadammina macrescens; N: number of individuals; $\mathrm{S}$ : number of species; P/T: Planktonics /total Forams.

\begin{tabular}{|c|c|c|c|c|c|c|c|c|c|c|c|c|}
\hline $\begin{array}{l}\text { GER } 9 \\
\text { (unit) }\end{array}$ & $\begin{array}{l}-4 \\
\text { sample } \\
(\mathrm{cm})\end{array}$ & H.ger. & A.tep. & T. inf. & J. mac. & $\mathrm{N}$ & $\mathrm{S}$ & $\begin{array}{l}\text { Fisher's } \alpha \\
\text { index }\end{array}$ & $\mathrm{P} / \mathrm{T}$ & $\%$ Agglutinated & $\%$ Porcellaneous & $\%$ Hyaline \\
\hline 4 & $\begin{array}{c}1 \\
16 \\
25 \\
50 \\
75\end{array}$ & & & $\begin{array}{l}3 \\
1\end{array}$ & 49 & $\begin{array}{c}49 \\
0 \\
6 \\
1 \\
0\end{array}$ & $\begin{array}{l}2 \\
3 \\
3\end{array}$ & $\begin{array}{l}1 \\
1 \\
1\end{array}$ & & $\begin{array}{l}100 \\
100 \\
100\end{array}$ & & \\
\hline 3 & $\begin{array}{l}100 \\
125 \\
150 \\
175 \\
187 \\
199 \\
212 \\
224 \\
250 \\
275 \\
300 \\
325 \\
337 \\
350 \\
362 \\
375 \\
400 \\
425 \\
450 \\
475\end{array}$ & 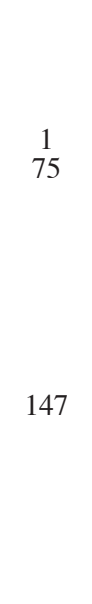 & 19 & $\begin{array}{c}4 \\
6 \\
48 \\
28 \\
27 \\
68 \\
42 \\
107 \\
4 \\
3 \\
5 \\
10 \\
3 \\
14 \\
\\
4 \\
3 \\
15 \\
9 \\
49\end{array}$ & $\begin{array}{c}7 \\
17 \\
43 \\
4 \\
132 \\
18 \\
188 \\
1 \\
5 \\
8 \\
3 \\
40 \\
\\
5 \\
2 \\
24 \\
16 \\
20\end{array}$ & $\begin{array}{c}11 \\
6 \\
66 \\
72 \\
33 \\
307 \\
62 \\
295 \\
5 \\
8 \\
13 \\
13 \\
3 \\
302 \\
0 \\
9 \\
6 \\
39 \\
25 \\
69\end{array}$ & $\begin{array}{c}3 \\
3 \\
4 \\
4 \\
5 \\
11 \\
4 \\
3 \\
3 \\
3 \\
3 \\
3 \\
3 \\
13 \\
\\
3 \\
4 \\
3 \\
3 \\
3\end{array}$ & $\begin{array}{l}1 \\
1 \\
1 \\
1 \\
1 \\
2 \\
1 \\
1 \\
1 \\
1 \\
1 \\
1 \\
1 \\
3 \\
\\
1 \\
1 \\
1 \\
1 \\
1\end{array}$ & 更 & $\begin{array}{l}100 \\
100 \\
100 \\
100 \\
94 \\
65 \\
97 \\
100 \\
100 \\
100 \\
100 \\
100 \\
100 \\
18 \\
\\
100 \\
100 \\
100 \\
100 \\
100\end{array}$ & $\begin{array}{l}3 \\
3\end{array}$ & 更 \\
\hline 2 & $\begin{array}{l}487 \\
500 \\
512 \\
525 \\
537\end{array}$ & $\begin{array}{c}138 \\
105 \\
191 \\
13 \\
2\end{array}$ & $\begin{array}{c}52 \\
50 \\
55 \\
7\end{array}$ & $\begin{array}{c}20 \\
84 \\
4 \\
38 \\
6\end{array}$ & $\begin{array}{l}15 \\
61 \\
42 \\
34 \\
10\end{array}$ & $\begin{array}{c}246 \\
324 \\
312 \\
98 \\
18\end{array}$ & $\begin{array}{c}8 \\
10 \\
8 \\
6 \\
4\end{array}$ & $\begin{array}{c}1.5 \\
2 \\
1.5 \\
1.5 \\
1\end{array}$ & $\begin{array}{c}1 \\
10\end{array}$ & $\begin{array}{l}14 \\
45 \\
15 \\
73 \\
89\end{array}$ & & $\begin{array}{l}86 \\
55 \\
85 \\
27 \\
11\end{array}$ \\
\hline 1 & $\begin{array}{l}550 \\
562 \\
575 \\
587 \\
600 \\
625 \\
650 \\
662 \\
675 \\
700 \\
720 \\
726\end{array}$ & $\begin{array}{c}144 \\
130 \\
159 \\
62 \\
109 \\
134 \\
98 \\
49 \\
87 \\
128 \\
171\end{array}$ & $\begin{array}{c}123 \\
132 \\
106 \\
86 \\
53 \\
135 \\
166 \\
237 \\
174 \\
172 \\
124\end{array}$ & $\begin{array}{c}1 \\
2 \\
3 \\
30\end{array}$ & $\begin{array}{c}1 \\
2 \\
3 \\
20 \\
65 \\
18 \\
\\
2\end{array}$ & $\begin{array}{c}0 \\
317 \\
330 \\
310 \\
197 \\
278 \\
307 \\
297 \\
322 \\
305 \\
315 \\
318\end{array}$ & $\begin{array}{c}10 \\
13 \\
15 \\
8 \\
9 \\
7 \\
11 \\
6 \\
10 \\
10 \\
11\end{array}$ & $\begin{array}{c}2 \\
3.5 \\
3.5 \\
1.5 \\
1.5 \\
1.5 \\
2 \\
1 \\
1.5 \\
1.5 \\
2\end{array}$ & $\begin{array}{l}1 \\
1 \\
1 \\
1 \\
1 \\
1 \\
1 \\
1 \\
1\end{array}$ & $\begin{array}{c}1 \\
2 \\
12 \\
34 \\
6 \\
1\end{array}$ & $\begin{array}{l}1 \\
2 \\
1\end{array}$ & $\begin{array}{c}99 \\
97 \\
97 \\
88 \\
66 \\
94 \\
99 \\
99 \\
100 \\
100 \\
98\end{array}$ \\
\hline
\end{tabular}




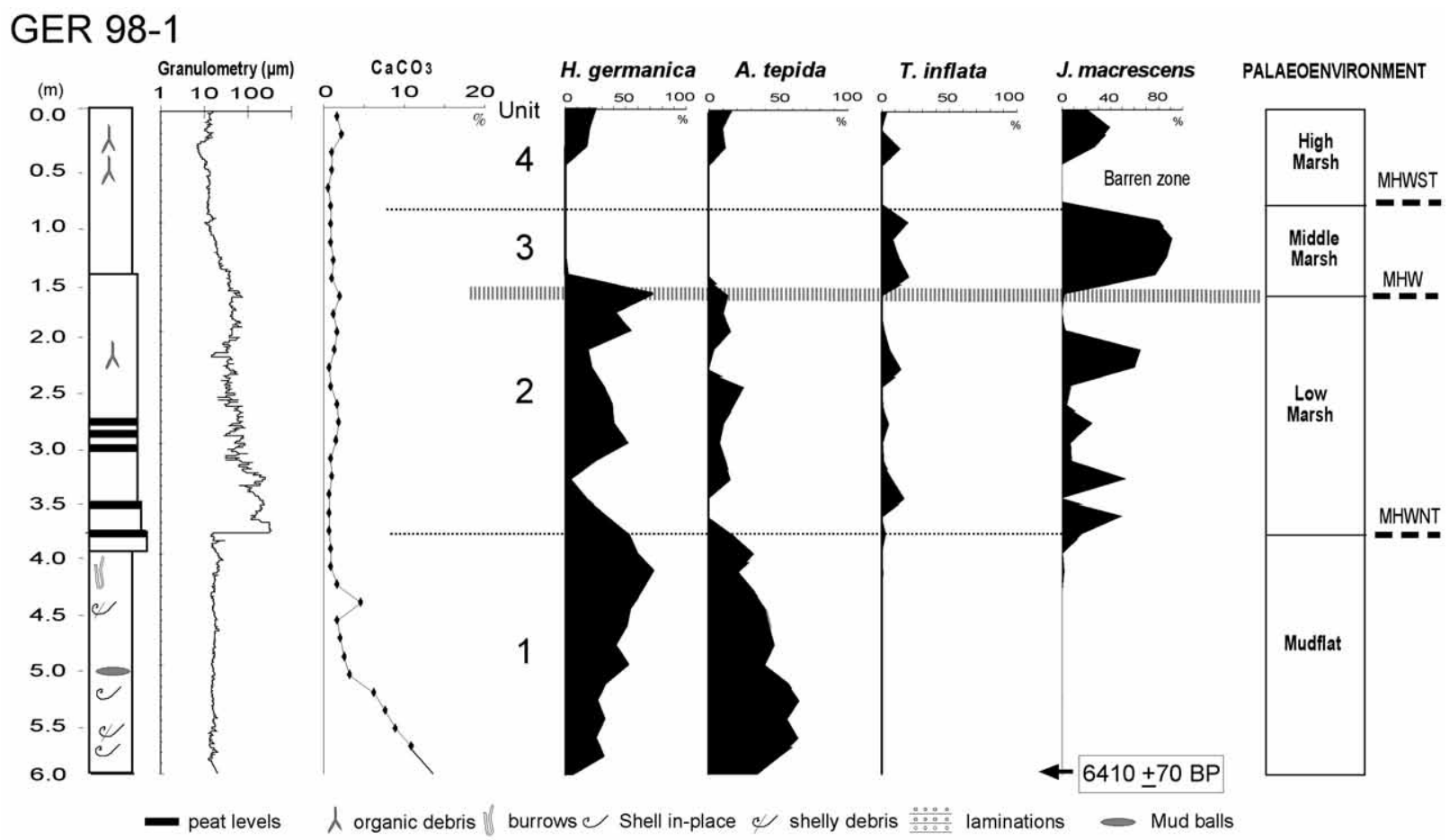

FIG. 3. - Stratigraphy of core GER 98-1. Legend as in Figure 2.

- Unit 1. From the bottom base of the core up to $550 \mathrm{~cm}$ (core depth), there is a laminated deposit of silts (mean grain size $=14 \mu \mathrm{m}$ ) with some sharp contacts and bioturbated horizons. The carbonate content is less than $5.29 \%$. This unit is dominated by the benthic foraminifer assemblage composed of A. tepida, C. williamsoni and $H$. germanica, which accounts for $63 \%$ of the total assemblages. Calcitic hyaline tests strongly dominate among the foraminifers (Table 1). Species diversity is low ( $\mathrm{S}=6-15 ; \alpha=1-3.5$ ), and planktonic foraminifers are very scarce $(<1 \%)$. In these levels there are also Bolivina pseudoplicata, Brizalina spathulata, Bulimina gibba, Fissurina orbignyana and Globocassidulina subglobosa, accounting for $6 \%$ of the samples. At the top of this unit foraminifers are absent.

- Unit $2(550 \mathrm{~cm}$ to $487 \mathrm{~cm})$. The sediment is coarser than in Unit 1 (mean grain size $=26 \mu \mathrm{m})$, and the carbonate content is slightly higher (up to $7.18 \%$ ). Shells of molluscs, some broken, are concentrated at these levels. Planktonic foraminifers are visible $(10 \%)$ at the base of the unit (Table 1). Radiocarbon dating at $537 \mathrm{~cm}$ gives an age of 4640 \pm 40 years BP. The assemblage is dominated by $A$. tepida and $H$. germanica, as well as the agglutinated Jadammina macrescens and Trochammina infla$t a$, which are more abundant in the lower levels. Diversity is relatively low $(S=4-10 ; \alpha=1-2)$.
- Unit $3(487 \mathrm{~cm}$ to $100 \mathrm{~cm})$. Above a sharp contact is a horizon of silt and clay (mean grain size $=$ $20 \mu \mathrm{m}$ ), with low-carbonate levels (mean $=1.2 \%$ ). Low percentages of foraminifers are found $(\mathrm{S}=3-5$; $\alpha=1$ ); the species $J$. macrescens and T. inflata dominate, except at $350 \mathrm{~cm}$, where the assemblage is composed of A. tepida, C. williamsoni and H. germanica $(75 \%)$. The diversity of this sample is locally increased by the occurrence of other species, such as Asterigerinata mamilla, B. gibba, B. pygmaea, Brizalina subaenariensis and L. lobatula, $(\mathrm{S}=13$, $\alpha=3$ ) (Table 1). The occurrence of high numbers of individuals of $H$. germanica and L. lobatula at 199 $\mathrm{cm}$ increases diversity up to 11 species in this particular level.

- Unit 4 (100 cm to core top). This consists of a grey to reddish clay (mean size $=8 \mu \mathrm{m}$ ) with rootlet remains and organic matter, and almost without carbonate $($ mean $=0.9 \%)$. Foraminifers are scarce $(\mathrm{S}$ $<3, \alpha<1$ ), and the only agglutinated species are J. macrescens and T. inflata (Fig. 2).

\section{Core GER 98-1}

This core is located on the eastern margin of the estuary, $510 \mathrm{~m}$ from the main channel $\left(43^{\circ} 20.8^{\prime} \mathrm{N}\right.$ $\left.2^{\circ} 39.5^{\prime} \mathrm{W}\right)$. Six metres of sediments were drilled in a cultivated area $2.9 \mathrm{~m}$ above the MMSL (modern 
TABLE 2. - Microfaunal (benthic foraminifer) database of core GER 98-1. The number of individuals, richness and species diversity indices, planktonic foraminifer and test composition percentages are shown. Species distribution is shown only for the four species used in this work. H.ger.: Haynesina germanica; A.tep.: Ammonia tepida; T. inf.: Trochammina inflata; J. mac.: Jadammina macrescens; N: number of individuals; S: number of species; P/T: Planktonics /total Forams.

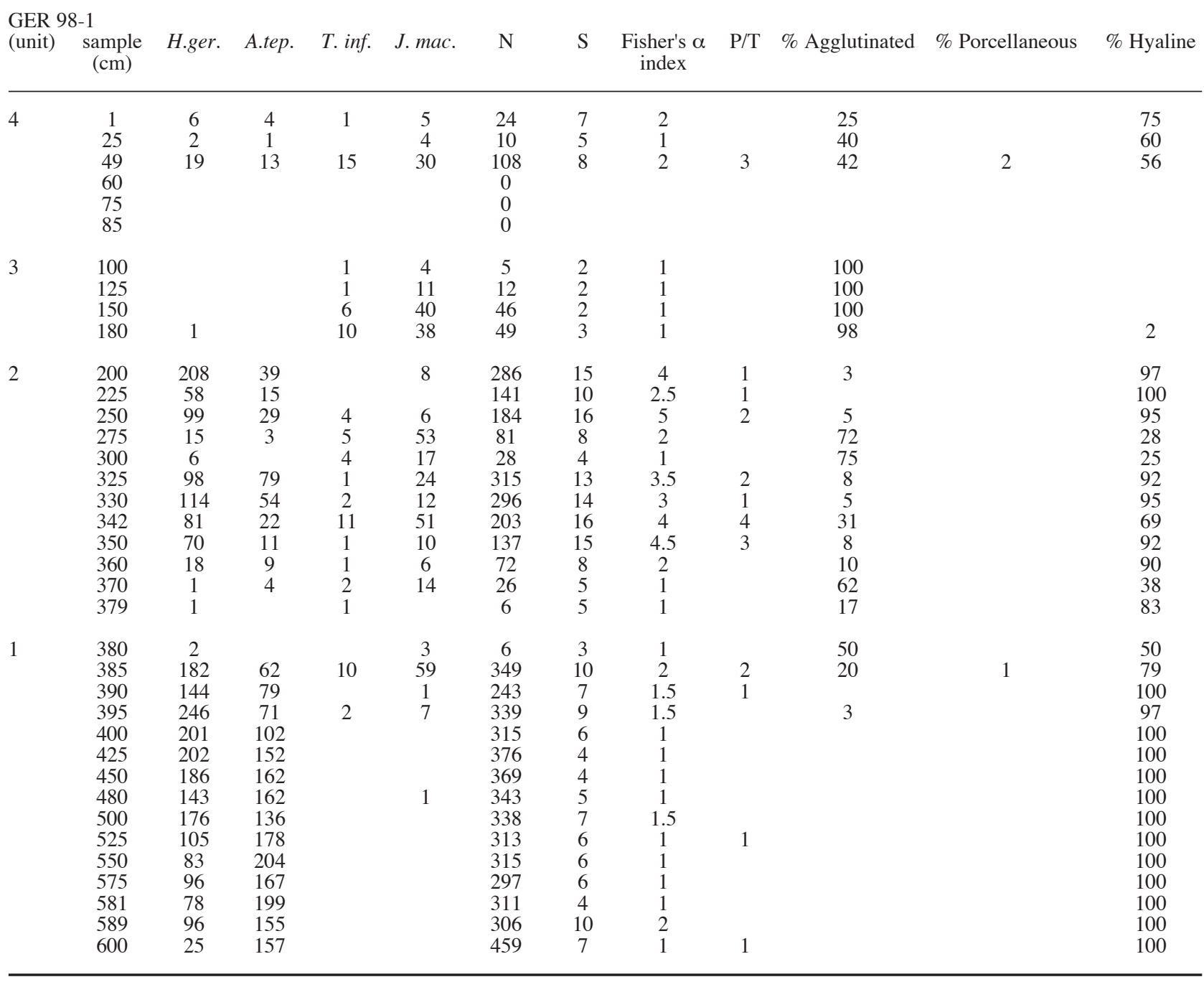

mean sea level, see Fig. 1). The 36 samples studied yielded a total of 6702 specimens of benthic foraminifers, and 43 species were taxonomically described. Their distribution throughout the core shows four units (Fig. 3).

- Unit 1 ranges from the base up to $385 \mathrm{~cm}$ (core depth). It is a compacted fine grey silt (mean grain size $=16 \mu \mathrm{m}$ ) with mollusc shell fragments and low carbonate (mean $=4 \%)$. The dominant assemblage of benthic foraminifers is composed of $C$. williamsoni, A. tepida and $H$. germanica. In the lower interval $(600-590 \mathrm{~cm})$ the first of these species accounts for $60 \%$ of the total population. More than $79 \%$ of the tests are hyaline (Table 2). The diversity is very low $(\mathrm{S}<10 ; \alpha<2)$ and the planktonic representatives of the foraminifers also occur in very low percentages
$(<2 \%)$. Radiocarbon dating of the sample at $600 \mathrm{~cm}$ shows an age of $6410 \pm 70$ years BP.

- Unit $2(385 \mathrm{~cm}$ to $180 \mathrm{~cm})$. A sequence of upward thinning (decreasing grain size) occurs above an erosive surface. It is composed of some brown, middle to coarse sandy levels and a grey laminated silt with black organic horizons. Carbonate is very low (mean $=1.2 \%$ ). The main foraminifer assemblage is composed of the same species as in the Unit 1, plus L. lobatula, J. macrescens and T. inflata. The diversity indices and secondary species indicate the presence of two subunits. In the first $(380 \mathrm{~cm}$ to $325 \mathrm{~cm})$ the percentages of agglutinated foraminifers decrease to very low levels (62 to 5\%), while diversity increases ( $\mathrm{S}$, from 3 to 16 ; $\alpha$, from 1 to 4.5$)$. In the few uppermost cen- 
timetres of this subunit another assemblage occurs, with the species B. spathulata, B. gibba, G. subglobosa, Rosalina globularis and Trifarina angulosa. Planktonic foraminifers also appear at these levels (up to $4 \%$ ). In the second subunit (325 to $200 \mathrm{~cm}$ ) similar decreases in the agglutinated foraminifers (75\% to $3 \%)$ and increases in diversity (S, 4-15; $\alpha$ from 1 to 4 ) and planktonics (2\%) to modern levels are observed.

- Unit $3(180 \mathrm{~cm}$ to $85 \mathrm{~cm})$. Another thinning upward sequence occurs, from grey, siliceous fine sands (mean grain size $=29.3 \mu \mathrm{m}$ ) at the bottom to lighter silts with some black organic horizons at the top. Carbonate is very low (mean $=1 \%$ ). Foraminifer calcareous tests disappear in these levels, and the assemblages are composed exclusively of agglutinated species: J. macrescens $(>80 \%)$ and T. inflata. Diversity is very low ( $\mathrm{S}<3 ; \alpha<1)$.

- Unit 4 (from $85 \mathrm{~cm}$ to core top). Sediment is brown silt (mean grain size $=14 \mu \mathrm{m}$ ) with abundant rootlet remains, indicative of paedogenetic processes. Carbonate is very low (mean $=1.2 \%$ ). No foraminifers occur within the interval 85 to $50 \mathrm{~cm}$. At modern horizons there are some specimens of the estuarine species mentioned above (see Fig. 3) in assemblages with very low diversity $(\mathrm{S}<8 ; \alpha<2)$ (Table 2).

\section{Core GER 98-3}

This is a $7.11 \mathrm{~m}$ continuous core, located on the eastern margin of the estuary, at $+3.20 \mathrm{~m}$ above MMSL and $750 \mathrm{~m}$ from the main channel $\left(43^{\circ} 22.1^{\prime} \mathrm{N}-2^{\circ} 40.2^{\prime} \mathrm{W}\right.$; Fig. 1$)$. In the 34 samples studied, a total of 5395 specimens of benthic foraminifers belonging to 87 species were analysed. Four different units are distinguished (Fig. 4):

- Unit 1 (from the core bottom to $325 \mathrm{~cm}$ core depth) is composed lithologically of yellowish mid-sized (mean $280 \mu \mathrm{m}$ ) sands with shell remains. Carbonate content averages $14 \%$. Radiographic analyses show two different horizons in these coarse basal facies. From $550 \mathrm{~cm}$ an upward thinning sequence occurs. Shells from this level have been radiocarbon dated at $5010 \pm 60$ years B.P. The benthic foraminifer assemblage of the unit, composed of L. lobatula, E. crispum, $R$. globularis and $Q$. seminula, is dominant, accounting for more than $50 \%$ of the total individuals. Hyaline tests are dominant $(>81 \%)$ and the porcel-

\section{GER 98-3}

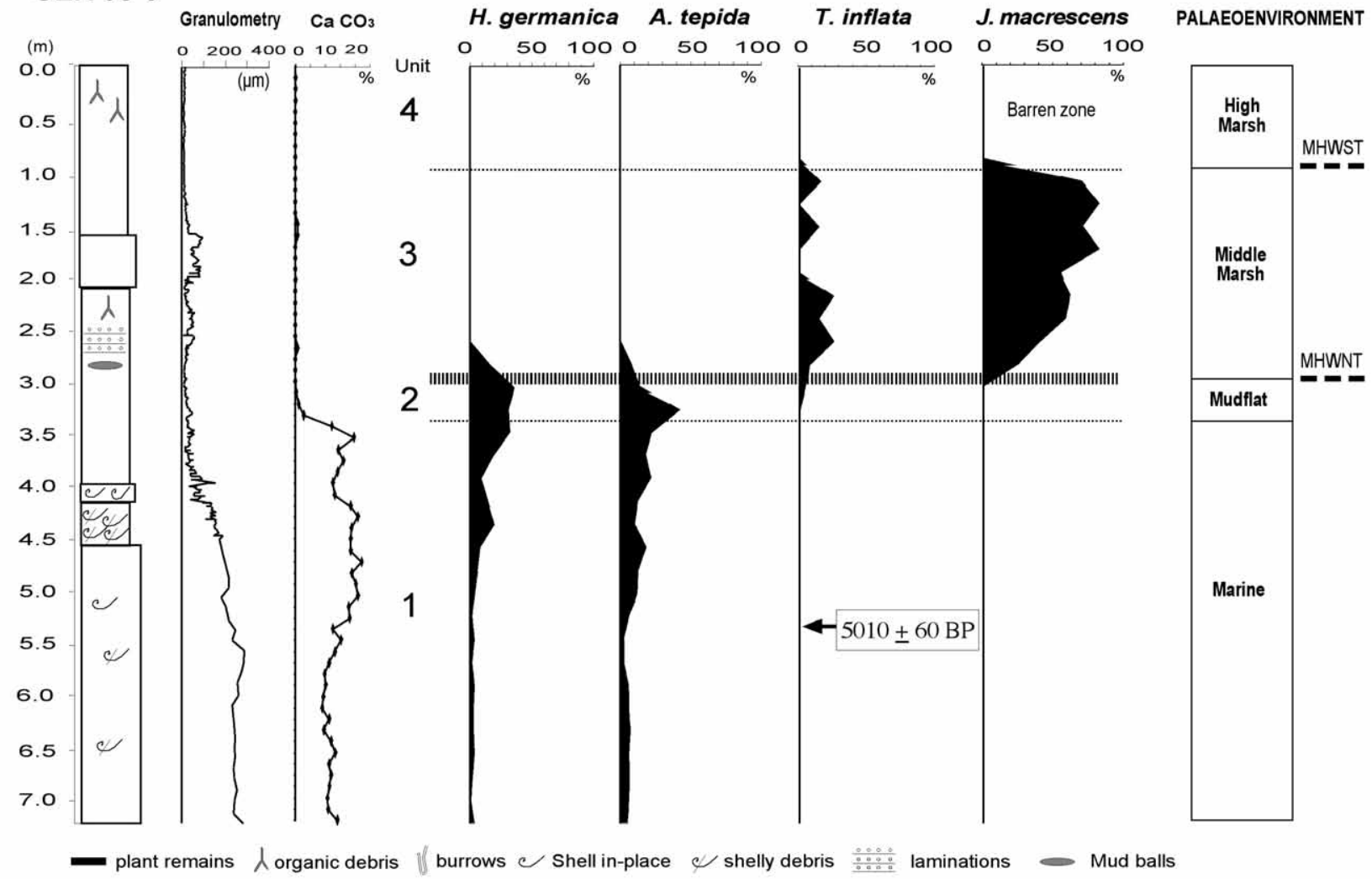

FIG. 4. - Stratigraphy of core GER 98-3. Legend as in Figure 2. 
TABLE 3. - Microfaunal (benthic foraminifer) database of core GER 98-3. The number of individuals, richness and species diversity indices, planktonic foraminifer and test composition percentages are shown. Species distribution is shown only for the four species used in this work. H.ger.: Haynesina germanica; A.tep.: Ammonia tepida; T. inf.: Trochammina inflata; J. mac.: Jadammina macrescens; N: number of individuals; S: number of species; P/T: Planktonics /total Forams.

\begin{tabular}{|c|c|c|c|c|c|c|c|c|c|c|c|c|}
\hline $\begin{array}{l}\text { GER 9 } \\
\text { (unit) }\end{array}$ & $\begin{array}{l}\text { 8-3 } \\
\text { sample } \\
(\mathrm{cm})\end{array}$ & H.ger. & A.tep. & T. inf. & J. mac. & $\mathrm{N}$ & S & $\begin{array}{l}\text { Fisher's } \alpha \\
\text { index }\end{array}$ & $\mathrm{P} / \mathrm{T}$ & $\%$ Agglutinated & $\%$ Porcellaneous & $\%$ Hyaline \\
\hline 4 & $\begin{array}{c}1 \\
25 \\
50 \\
75\end{array}$ & & & & & & & & & & & \\
\hline 3 & $\begin{array}{l}100 \\
125 \\
150 \\
175 \\
200 \\
225 \\
250 \\
275\end{array}$ & & & $\begin{array}{l}2 \\
1 \\
1 \\
1\end{array}$ & $\begin{array}{c}11 \\
11 \\
6 \\
1 \\
2 \\
3 \\
5\end{array}$ & $\begin{array}{l}13 \\
11 \\
7 \\
1 \\
3 \\
4 \\
7\end{array}$ & $\begin{array}{l}2 \\
1 \\
2 \\
1 \\
2 \\
2 \\
2\end{array}$ & $\begin{array}{l}1 \\
1 \\
1 \\
1 \\
1 \\
1 \\
1\end{array}$ & . & $\begin{array}{c}100 \\
100 \\
100 \\
100 \\
100 \\
100 \\
86\end{array}$ & & 14 \\
\hline 2 & $\begin{array}{l}300 \\
312 \\
315 \\
318 \\
321\end{array}$ & $\begin{array}{c}2 \\
8 \\
103 \\
120\end{array}$ & $\begin{array}{c}1 \\
3 \\
139 \\
82\end{array}$ & $\begin{array}{l}1 \\
1 \\
1 \\
2 \\
1\end{array}$ & $\begin{array}{l}2 \\
4\end{array}$ & $\begin{array}{c}4 \\
13 \\
22 \\
328 \\
366\end{array}$ & $\begin{array}{c}3 \\
8 \\
9 \\
25 \\
28\end{array}$ & $\begin{array}{c}1 \\
1.5 \\
2.4 \\
6 \\
7.5\end{array}$ & $\begin{array}{l}7 \\
4 \\
2 \\
2\end{array}$ & $\begin{array}{c}75 \\
38 \\
4 \\
1 \\
2\end{array}$ & 8 & $\begin{array}{l}25 \\
54 \\
96 \\
99 \\
98\end{array}$ \\
\hline 1 & $\begin{array}{l}325 \\
330 \\
350 \\
375 \\
386 \\
400 \\
425 \\
460 \\
495 \\
515 \\
550 \\
575 \\
600 \\
630 \\
650 \\
675 \\
700\end{array}$ & $\begin{array}{c}53 \\
32 \\
47 \\
61 \\
26 \\
19 \\
12 \\
5 \\
12 \\
4 \\
11 \\
4 \\
6 \\
10 \\
6 \\
3 \\
11\end{array}$ & $\begin{array}{c}50 \\
75 \\
40 \\
33 \\
56 \\
39 \\
38 \\
21 \\
9 \\
7 \\
19 \\
10 \\
15 \\
18 \\
22 \\
20 \\
16\end{array}$ & 1 & 1 & $\begin{array}{l}277 \\
343 \\
318 \\
310 \\
302 \\
302 \\
313 \\
325 \\
333 \\
258 \\
302 \\
157 \\
203 \\
284 \\
316 \\
310 \\
306\end{array}$ & $\begin{array}{l}17 \\
20 \\
27 \\
29 \\
34 \\
26 \\
25 \\
26 \\
25 \\
24 \\
28 \\
16 \\
29 \\
29 \\
32 \\
36 \\
34\end{array}$ & $\begin{array}{c}4 \\
4.5 \\
7 \\
8 \\
10 \\
7 \\
6.5 \\
7 \\
6 \\
7 \\
7 \\
4 \\
10 \\
8 \\
9 \\
12 \\
10\end{array}$ & $\begin{array}{c}3 \\
3 \\
4 \\
3 \\
2 \\
2 \\
4 \\
2 \\
3 \\
\\
1 \\
2 \\
1 \\
1 \\
2 \\
0.5 \\
2\end{array}$ & $\begin{array}{l}1 \\
2 \\
1 \\
1 \\
1 \\
1 \\
5 \\
5 \\
1 \\
1 \\
3 \\
2 \\
3 \\
6 \\
5 \\
3 \\
7\end{array}$ & $\begin{array}{c} \\
6 \\
4 \\
9 \\
5 \\
6 \\
6 \\
6 \\
7 \\
5 \\
10 \\
11 \\
9 \\
14 \\
16 \\
9\end{array}$ & $\begin{array}{l}99 \\
98 \\
93 \\
95 \\
90 \\
94 \\
89 \\
89 \\
93 \\
92 \\
92 \\
88 \\
86 \\
85 \\
81 \\
81 \\
84\end{array}$ \\
\hline
\end{tabular}

laneous type accounts for $16 \%$ (Table 3 ). Diversity is high (S, 16 to $36 ; \alpha, 4$ to 12 ). Planktonic foraminifers regularly occur but never at more than $4 \%$. As a secondary assemblage, we can mention $A$. mamilla, B. pseudoplicata, B. gibba, Entosolenia squamosa, G. subglobosa, Planorbulina acervalis, Planorbulina mediterranensis and Trifarina bradyi.

- Unit 2 (from $325 \mathrm{~cm}$ to $300 \mathrm{~cm}$ ) is composed of grey sandy silts (mean grain size $=27.2 \mu \mathrm{m}$ ) and low carbonate content (mean 1.4\%). The assemblage is dominated by the species A. tepida, $C$. williamsoni and $H$. germanica (55-84\%). Hyaline tests are still the most important in percentage terms $(>95 \%)$, and diversity decreases slightly ( $\mathrm{S}=9-28 ; \alpha<7.5)$. Planktonics maintain similar percentages to the previous unit. In the final levels $(314 \mathrm{~cm}$ to $312 \mathrm{~cm})$ there is an assemblage composed of L. lobatula, E. crispum, $R$. globularis, $Q$. seminula, A. tepida, $C$. williamsoni, H. germanica, J. macrescens and T. inflata.

- Unit $3(300 \mathrm{~cm}$ to $100 \mathrm{~cm})$. From $300 \mathrm{~cm}$ up to $280 \mathrm{~cm}$ there is grey silt (mean grain size $=33.6$ $\mu \mathrm{m})$; carbonate is practically absent. After this there are two levels of fine sands in a clay material. Agglutinated foraminifers (J. macrescens and $T$. inflata, $>85 \%$ ) dominate this interval with very low diversity (S <3; $\alpha<1)$ (Table 3 ). No planktonic foraminifers have been found in this unit, except at $275 \mathrm{~cm}$, where they account for $11 \%$.

- Unit 4. From $100 \mathrm{~cm}$ to the core top. The sediment is very fine (mean grain size $=12 \mu \mathrm{m}$ ), with no carbonate, and radiographic analyses show a dense network of rootlets crossing fine sub-horizontal laminations. No microfauna occurs in this unit. 


\section{Core GER 98-5}

A total of $6.56 \mathrm{~m}$ of continuous sediment was drilled in this core, located at $+2.20 \mathrm{~m}$ above MMSL, in a lower marsh area $950 \mathrm{~m}$ from the active channel $\left(43^{\circ} 22.8^{\prime} \mathrm{N}, 2^{\circ} 41.5^{\prime} \mathrm{W}\right)$. The forty-nine samples analysed yielded 8075 individuals of foraminifers, grouped into 72 species. Based on the granulometry and the assemblage-type, four units can be distinguished (Fig. 5):

- Unit 1 (from the base to $505 \mathrm{~cm}$ ). Brownish to green medium-grained sand $(250 \mu \mathrm{m})$ with oblique laminations is deposited at these levels. Carbonate content averages $15.8 \%$. At $564 \mathrm{~cm}$ there is a horizon with clay balls and shell fragments. The foraminifer assemblage is dominated by $L$. lobatu$l a$ and $R$. globularis. Diversity is high ( $\mathrm{S}=17-31$, $\alpha=5-8$; Table ). Calcareous tests are very significant in percentage terms, particularly the hyalines, but the porcellaneous type is also noticeable (up to $18 \%)$. Planktonic foraminifers occur in very low numbers $(<4 \%)$.

- Unit $2(505 \mathrm{~cm}$ to $300 \mathrm{~cm})$ consists of grey silt (10-15 um) finely laminated with mollusc shells that are occasionally concentrated in some levels. The carbonate content decreases progressively from the base $(11.6 \%)$ towards the top $(0.5 \%)$ of this unit. The dominant assemblage is composed of A. tepida and $H$. germanica. Hyaline tests are dominant $(>84 \%)$, and the diversity decreases progressively upwards (S, 26 to $15 ; \alpha, 6$ to 3 , see Table 4). A ${ }^{14} \mathrm{C}$ radiocarbon dating of the sample at $358 \mathrm{~cm}$ gave an age of $4200 \pm 40$ years B.P.

- Unit $3(300 \mathrm{~cm}$ to $125 \mathrm{~cm})$. In the basal interval $(300 \mathrm{~cm}$ to $268 \mathrm{~cm}$ ) the grain size of the sediment and the carbonate content increase. The species $A$. tepida is dominant, accounting for more than $95 \%$ of the foraminifer assemblages. Diversity is noticeably lower than in the previous unit $(\mathrm{S}<9, \alpha<1.5)$. All the tests are hyaline and no planktonic foraminifers occur. In the upper interval $(268 \mathrm{~cm}$ to $125 \mathrm{~cm}$ ) a brownish, medium-sized sand (mean grain size $=130 \mu \mathrm{m}$ ) is organised into two thinningupward sequences, each starting with a shell-bearing level at the base. Carbonate content reaches $16 \%$ at the top of this unit. Benthic foraminifer assemblages are also distributed differently through the sequences, starting with $L$. lobatula, E. crispum, $R$. globularis and $Q$. seminula at the base, A. tepida, $C$. williamsoni and $H$. germanica in the middle, and $J$. macrescens and $T$. inflata at the top of the unit. Diversity varies from high at the base of the

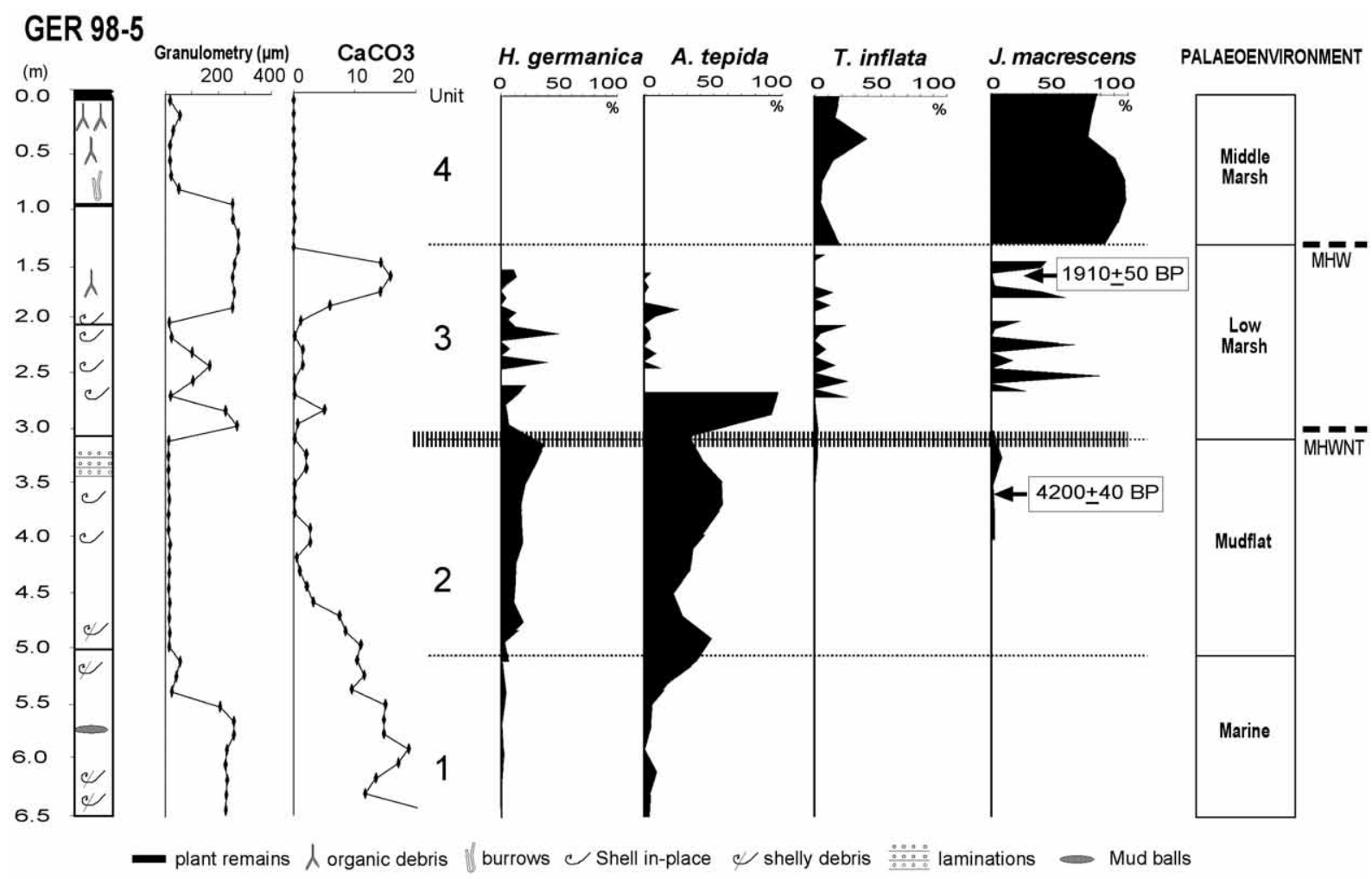

FIG. 5. - Stratigraphy of core GER 98-5. Legend as in Figure 2. 
TABLE 4. - Microfaunal (benthic foraminifer) database of core GER 98-5. The number of individuals, richness and species diversity indices, planktonic foraminifer and test composition percentages are shown. Species distribution is shown only for the four species used in this work. H.ger.: Haynesina germanica; A.tep.: Ammonia tepida; T. inf.: Trochammina inflata; J. mac.: Jadammina macrescens; N: number of individuals; S: number of species; P/T: Planktonics /total Forams.

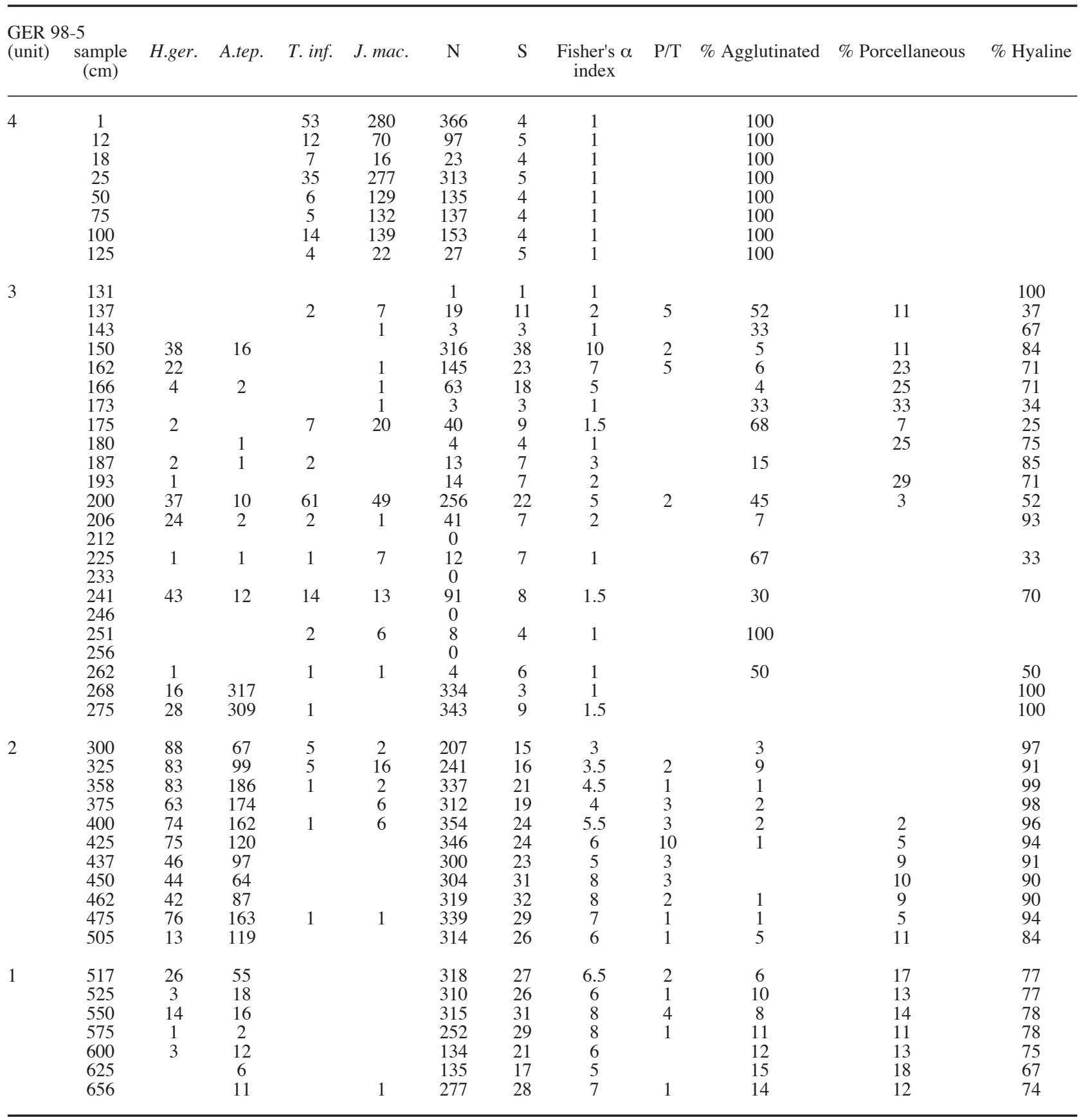

sequences to low at the top, with several horizons depleted of foraminifers $(256,246,233,212 \mathrm{~cm})$. At two particular levels the diversity is very high $(\mathrm{S}=$ 22 species, $\alpha=5$, at $200 \mathrm{~cm} ; \mathrm{S}=38$ species, $\alpha=10$, at $150 \mathrm{~cm}$; see Table 4). As well as the assemblages discussed above, the other species which occur in this interval cause the increase in diversity: $B . s u b$ aenariensis, Brizalina variabilis, Cassidulina obtusa and G. subglobosa. Planktonic foraminifers account for up to $5 \%$ in this particular interval. ${ }^{14} \mathrm{C}$ radiocarbon dating of the sample at $162 \mathrm{~cm}$ is 1910 \pm 50 years B.P.

- Unit 4 (from $125 \mathrm{~cm}$ to core top) is composed of grey-brownish clayey silt (mean grain size = $23 \mu \mathrm{m}$ ) with abundant rootlets in the top $80 \mathrm{~cm}$. Carbonate is absent. The dominant assemblage is 
formed by $J$. macrescens and $T$. inflata, and Miliammina fusca also occurs in the last $12 \mathrm{~cm}$. Diversity is very low in this unit $(S<5, \alpha=1)$. All the foraminifers are from agglutinated tests.

\section{DISCUSSION}

\section{Benthic foraminifer ecology}

The species of benthic foraminifers studied in these cores are currently living on sediments in the southern Bay of Biscay (Cearreta, 1988, 1989; Pascual et al., 1991; Pascual, 1992) and along the whole of the North Atlantic (Murray, 1991). Different assemblages can define a particular environment within an estuary (see Table 5). Thus, $Q$. seminula, E. crispum, L. lobatula and $R$. globularis live today in inner shelf marine environments (IS), and also occur in outer estuaries with salinity levels of 32-34\%o. A. tepida, C. williamsoni and H. germanica form an assemblage typical of subtidal euryhaline areas, occurring at the heads of estuaries (mud) with very variable salinity (1-32). $J$. macrescens and $T$. inflata characterise vegetated marshland. Other assemblages are exotic components in estuaries, and are composed of small individuals carried there by tidal currents. These assemblages are: A. mamilla, B. pseudoplicata, B. pygmaea, B. spathulata, B. subaenariensis, B. gibba, $C$. obtusa, F. hexagona, F. orbignyana, G. subglobosa, $P$. acervalis, $P$. mediterranensis and T. bradyi (see Table 5).

Quantification of diversity, e.g. via Fisher's $\alpha$ index, can also give important clues for the palaeoecological interpretation of these transitional areas. Murray (1991) defines values of $\alpha$ from 1 to 3 as characteristic of brackish marshes, and 5 to 19 of normal marine shelf settlements. Finally, the test composition of foraminifers can be used to run palaeoenvironmental analyses. Porcellaneous types (Milioliina) are present at the mouth of the estuary where hyaline tests (Rotaliina) dominate. Agglutinated foraminifers (Textulariina) are the only ones occurring in vegetated marshland, where the acidity of waters causes calcareous tests to dissolve (Murray, 1991).

Furthermore, some species of benthic foraminifers are distributed in estuaries according to tidal height (Scott and Medioli, 1986; Scott and Leckie, 1990;

TABLE 5. - Benthic foraminifer faunal reference list. The species mentioned in the text are ordered alphabetically, grouped as per test composition. The ecological preferences of the species are also indicated. Marsh = Brackish marsh; Mud = Mudflat; IS= Inner shelf $(0-100 \mathrm{~m})$; OS = Outer shelf $(100-200 \mathrm{~m})$; US= Upper slope $(200-2000 \mathrm{~m})$; LS = Lower slope $(2000-4000 \mathrm{~m})$.

Marsh Mud IS OS US LS

Agglutinated forms (Textulariina)

Jadammina macrescens (Brady) = Trochammina inflata (Montagu) var. macrescens Brady, 1870.

Miliammina fusca $($ Brady $)=$ Quinqueloculina fusca Brady, 1870 .

Trochammina inflata $($ Montagu $)=$ Nautilus inflatus Montagu, 1808.

$\begin{array}{llllll}X & - & - & - & - & - \\ X & - & - & - & - & - \\ X & - & - & - & - & - \\ & & & & & \\ - & - & X & - & - & - \\ & & & & & \\ - & X & - & - & - & - \\ - & - & X & X & - & - \\ - & - & X & X & - & - \\ - & - & X & X & - & - \\ - & - & X & X & - & - \\ - & - & X & X & - & - \\ - & - & X & X & - & - \\ - & - & X & X & - & - \\ - & - & - & X & X & X \\ - & X & - & - & - & - \\ - & - & X & X & - & - \\ - & - & X & X & - & - \\ - & - & X & X & - & - \\ - & - & - & X & X & X \\ - & X & - & - & - & - \\ - & - & X & X & - & - \\ - & - & X & - & - & - \\ - & - & X & - & - & - \\ - & - & X & - & - & - \\ - & - & - & X & X & - \\ - & - & - & X & X & -\end{array}$

Porcellaneous forms (Milioliina)

Quinqueloculina seminula $($ Linné $)=$ Serpula seminulum Linné, 1758.

\section{Hyaline forms (Rotaliina)}

Ammonia tepida $($ Cushman $)=$ Rotalia beccarii $($ Linné $)$ var. tepida Cushman, 1926.

Asterigerinata mamilla $($ Williamson $)=$ Rotalia mamilla Williamson, 1858.

Bolivina alata $($ Seguenza $)=$ Vulvulina alata Seguenza, 1862

Bolivina pseudoplicata Heron Allen and Earland, 1930.

Brizalina spathulata (Williamson) = Textularia variabilis Williamson var. spathulata Williamson, 1858.

Brizalina subaenariensis (Cushman) = Bolivina subaenariensis Cushman, 1922.

Brizalina variabilis $($ Williamson $)=$ Textularia variabilis Williamson, 1858.

Bulimina gibba = Fornasini, 1902

Cassidulina obtusa Williamson, 1858.

Cribroelphidium williamsoni $=$ Elphidium williamsoni Haynes, 1973.

Elphidium crispum (Linné) = Nautilus crispus Linné, 1758.

Favulina hexagona $($ Williamson $)=$ Entosolenia squamosa (Montagu) var. g hexagona Williamson, 1848 .

Fissurina orbignyana Seguenza, 1862.

Globocassidulina subglobosa $($ Brady) = Cassidulina subglobosa Brady, 1881

Haynesina germanica $($ Ehrenberg $)=$ Nonion germanicum Ehrenberg, 1840.

Lobatula lobatula $=$ Nautilus lobatulus Walker and Jacob, 1798.

Planorbulina acervalis Brady, 1884.

Planorbulina mediterranensis d'Orbigny, 1826.

Rosalina globularis d'Orbigny, 1826.

Trifarina angulosa $($ Williamson $)=$ Uvigerina angulosa Williamson, 1858.

Trifarina bradyi Cushman, 1923. 
Boomer, 1998; Haslett et al., 1998; Gehrels, 1999; Gehrels and Van de Plassche, 1999; Hippensteel et al., 2000). These authors have shown that a strong correlation exists between elevation above mean sea level and marsh foraminiferal populations. Thus, $H$. germanica lives on mudflats under the influence of any tide, then flooded by the MHWNT (Mean High Water Neap Tide). A. tepida is currently found dominating the low marsh, under the influence of the mean high waters (MHW). J. macrescens and T. inflata are representative of the middle marshes, which are flooded by the high tides during the spring (MHWST, Mean High Water Spring Tide). Finally, the occurrence of a few specimens of $J$. macrescens is indicative of high marsh areas that can be influenced only by the equinoctial tides (HAT, Highest Astronomical Tide). This species is also indicative of acidic (Scott and Medioli, 1986), and poorly oxygenated environments (Pujos, 1983).

Following these ideas, Haslett et al. (2001) proposed three zones of benthic foraminifers for saltmarshes in the Severn Estuary (UK). The H. germanica zone is defined by the continuous occurrence of the index species. It characterises the mudflat and the lower low marsh and is limited in its upper part by the MHWNT (Fig. 6). The A. beccarii (A. tepida in this work) zone is defined by its continuous occurrence, and defines the low marsh, located vertically between the MHWNT and the MHW. The middle marsh is characterised by the occurrence of the J. macrescens-T. inflata zone, limited at the top by the MHWST. A further barren zone is described by these authors as being typical of the high marsh environment, reached only by stronger tides during the equinoctial HAT. Only scattered individuals of $J$. macrescens can be found in the lower part of this zone.

These zones are depicted in Figure 6, where zones are distributed vertically according to the actual ranges of tides in the estuary of Gernika. By taking into consideration the model of Haslett et al. $(1998,2001)$ based on benthic foraminifer zones, it was possible to reconstruct the palaeoenvironment during the latter Holocene (the last $6.5 \mathrm{Ka}$ ), and to reveal evidence of sea-level changes.

\section{Palaeoenvironmental interpretation based on foraminifer assemblages}

Core GER 98-4 (see Fig. 2) shows the occurrence in its lower unit (Unit 1) of the species H. ger-

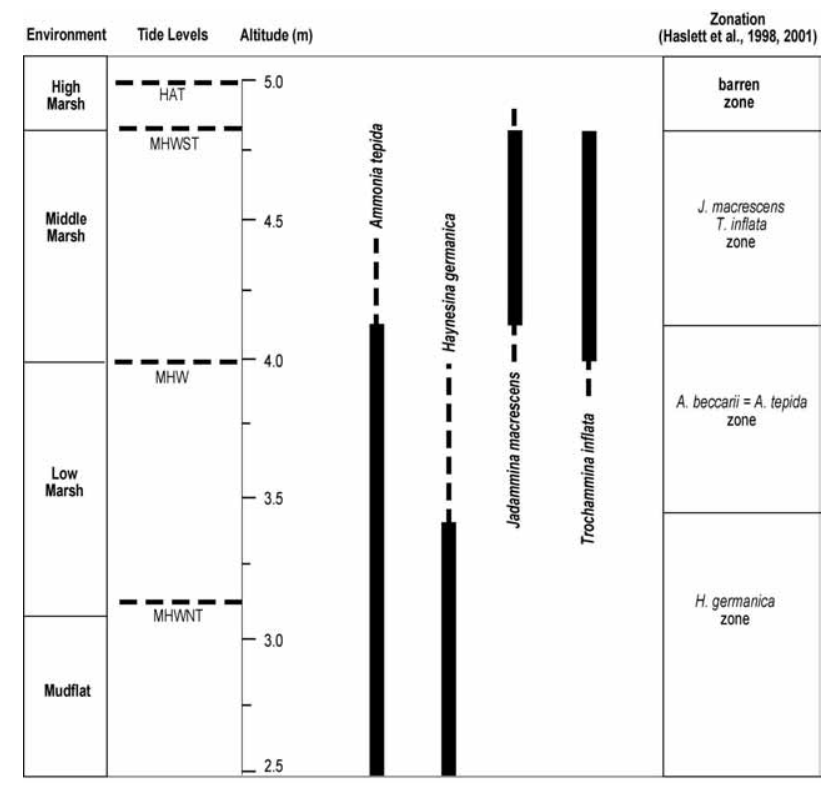

FIG. 6. - Benthic foraminiferal altitudinal distribution in the estuary of Gernika, based on the model of Haslett et al. $(1998,2001)$. Altitude of tide-levels is characteristic of the southern Bay of Biscay: HAT: + $4.99 \mathrm{~m}$; MHWST: + $4.87 \mathrm{~m}$; MHW: + $3.99 \mathrm{~m}$; MHWNT: $+3.21 \mathrm{~m}$.

manica and A. tepida which characterise the H. germanica zone, indicative of mudflats. This could represent an area continuously flooded by waters higher than $3.21 \mathrm{~m}$ (MHWNT, modern regional level), even during neaps. In Unit 2, both of these species progressively decrease and are replaced by $T$. inflata and $J$. macrescens, which become dominant through Unit 3. Unit 2 represents the A. tepida zone, indicative of a low marsh environment flooded by the mean tides of the area $(+3.99 \mathrm{~m}$, modern MHW). The low marsh was colonised in the area at about 4640 years BP, as indicated by the age in Unit 1 of Figure 2. Similarly, Unit 3 defines the $J$. macrescens-T. inflata zone, which is indicative of a middle marsh palaeoenvironment for this area of the estuary at the level of the MHWST (+ $4.87 \mathrm{~m}$, modern equivalent). Unit 4 of this core can be interpreted as being the lower part of the "barren zone" of the model, in which there is a very scarce occurrence of the index species. This interval can be interpreted as a high marsh, only reached by the waters during the HAT $(+4.99 \mathrm{~m})$. This core shows a clearly defined emergence sequence, as indicated by the temporal succession of foraminiferal zones and the sedimentological characters described above.

Applying the same criteria, Unit 1 of core GER 98-1 appears to be a mudflat under the influence of the MHWNT, at least from $6410 \pm 70$ years BP (see 
Fig. 3). Unit 2 belongs to the A. tepida zone, indicative of a lower marsh influenced by waters between MHWNT and MHW. The dominance of $J$. macrescens and $T$. inflata in Unit 3 defines this foraminiferal zone in the interval, characterising it as a middle marsh between MHT and MHWST influences. The absence of foraminifers in the lower part of Unit 4 (barren zone) indicates a high marsh environment. Finally, the occurrence of agglutinated species in the upper centimetres of this core could indicate some kind of reactivation of the channel during the general trend of filling of this part of the estuary, reverting it to low marsh conditions. This interpretation is supported by the occurrence of few planktonic foraminifers (see Table 2) in the middle part of Unit 4 (sample 49 $\mathrm{cm}$ ). Thus, this core also shows an emergent sequence, but with a pulsation close to the upper part of the core sequence.

The sediment of core GER 98-3, as drilled in the intermediate area of the estuary, shows a stronger marine influence than previous cores. This is evident in Unit 1 of this core (see Fig. 4), where the general foraminifer assemblages (species: $L$. lobatula, E. crispum, R. globularis, $Q$. seminula, and diversity: $\alpha$ index with high values, see Table 3 ) are indicative of a marine inner shelf. The progressive increase in the percentages of $H$. germanica, A. tepida and C. williamsoni in the upper levels of this unit points to the initiation of a mudflat, which becomes fully developed in Unit 2 . At the top of this unit, there is a mixing of species from marine shelf, mudflat and even vegetated marsh. Up to this time, all tides flooded this area, which was located below the MHWNT level. The dramatic increase of $J$. macrescens and the occurrence of T. inflata in Unit 3 are indicative of the foraminiferal zone, typical of a middle marsh palaeoenvironment. This middle marsh was under waters of MHW and MHWST levels. At level 275 $\mathrm{cm}$, a pulsation of marine waters is indicated by the occurrence of planktonic foraminifers (Table 3). The barren zone of Unit 4 shows the final sedimentary filling and development of a vegetated high marsh, which is under cultivation today. This core shows an emergent sequence extending over more than 5000 years.

Core GER 98-5 is located at the mouth of the estuary, and the influence of marine waters during the deposition of Unit 1 is evident (sands with $L$. lobatula and $R$. globularis, see Table 5). The benth- ic foraminiferal content of Unit 2 belongs to the $H$. germanica zone, indicative of a mudflat (see Fig. 5). This interval was under the range of all tides, below the MHWNT level. This environment developed in the area from at least 4200 years ago. During deposition of the lower part of Unit 3 there was a dramatic increase of A. tepida, showing the initiation of low marshland in the area. The upper interval of this unit is characterised by the occurrence of mixing, marine-estuarine assemblages of foraminifers, indicating a transitional oscillating environment, the modern terms of which are dated at about 2000 years ago. Since then, a middle marsh has been established in the area, as shown by the dominance of $J$. macrescens and T. inflata. These species define this zone, located between the influence of MHWST and HAT. This core represents an incomplete emergence sequence.

As demonstrated, the four cores studied represent a general emergent sequence, defined by the modern benthic foraminiferal zones proposed in the model of Haslett et al. (1998, 2001). The comparison of these cores provides a chronostratigraphic framework that explains the evolution of the different estuarine areas of Gernika during the latter part of the Holocene (Fig. 7). Figure 7 depicts the distribution in terms of geography and over time of different sub-environments in the estuary. The influence of the open sea is clearly shown to come from the north, reaching the middle estuary (cores 98-3, 985) during the Atlantic and part of the Subboreal stages, up to about 4700 years BP. Meanwhile, in the areas far from the sea (cores 98-1, 98-4) a mudflat environment was established during that time. The subsequent filling of the estuary is shown by the succession of shallowing facies defined by the benthic foraminiferal zones up to the high marsh, which are developing today in most of the estuary. In the outer area (core 98-5), due to the marine influence, the middle marsh is the shallowest environment registered during part of the Holocene that has been studied (see Fig. 7).

\section{Relative sea-level changes}

Coasts with rias were initially formed during periods of low sea-level, with erosion of fluvial valleys. During the Würm glaciation (11000 years BP) the coast of Urdaibai was located $12 \mathrm{~km}$ north of its modern position (Gobierno Vasco, 1993). Subsequently, as a result of the ice melting, the sea- 


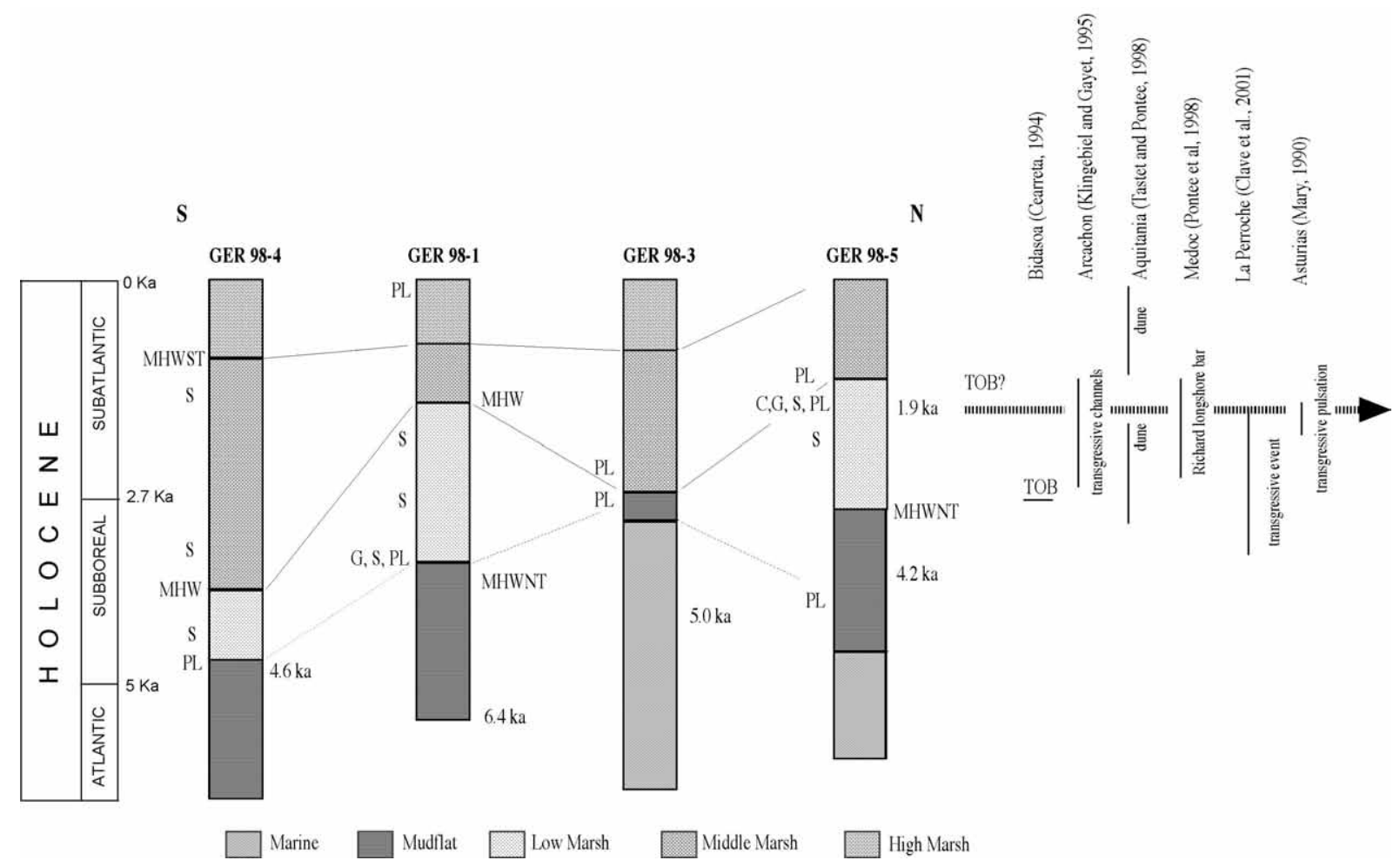

FIG. 7. - Stratigraphic correlations of cores studied in Gernika during the Holocene. Environmental units have been deduced from the benthic foraminifer zonal content. TOB is transgressive overlap boundary. PL, planktonic foraminifer occurrence. S, increase in species, G, increase in grain size values. $\mathrm{C}$, increase in carbonate values.

level began to rise and this caused the rias to fill with sediment.

Regional sea-level changes can be produced by global eustatism, holocene rising after glacial melt or by tectonic movements affecting coastal areas (Klingebiel and Gayet, 1995). Though this tectonism has been used to explain some aspects of the evolution of the south margin of the Bay of Biscay during the Neogene and Pleistocene (Mary, 1983). there is no evidence supporting holocene neotectonism in this region. Data from the Aquitaine coast in SW France (Klingebiel and Gayet, 1995) proposed a tectonic influence of 0 to $0.7 \mathrm{~mm}_{\text {year-1 }}{ }^{-1}$ to the general transgressive trend.

The estuarine filling of the rias in the southern Bay of Biscay started around 8000 years BP (Cearreta, 1992). In this study it has been shown that the filling occurred at least as of 6410 years BP. The sea-level rise has been considered as continuous by some authors, while others consider it to be a stepped process (Ters, 1973; Pujos, 1976; Pirazzoli, 1991; Stanley, 1995; Long, 2000). Some of these authors described several periods of high level, which were always placed below the modern mean sea-level. Fletcher et al. (1993) found that the sedimentary depositional environment in the saltmarshes in Wolfe Glade (Delaware Bay, USA) was controlled by sediment availability, tidal range and relative sea-level movements. These authors described five TOBs (Transgressive Overlap Boundaries) during the last $6 \mathrm{ka}$. These TOBs are interpreted as episodes of acceleration of the rate of sea-level rise relative to the rate of marsh aggradation. TOB episodes would thus indicate net sealevel rises (Fletcher et al., 1993). The above authors consider that TOBs T3 $(4400 \pm 200$ sidereal years $)$ and T6 $(1800 \pm 200$ sidereal years $)$ were the most important at basin scale, and could represent real eustatic rises.

Studies of cores from other estuaries of the Bay of Biscay have been made to detect these TOBs in the region. Cearreta and Murray (1996) describe a TOB surface in the ria of Santoña, in the context of a stepped rising of the sea-level in this area. Nevertheless the dating of this TOB was not possible with foraminifers due to the bad preservation of the tests (Cearreta and Murray, 2000). In the Bidasoa estuary Cearreta (1994) found a TOB at $2740 \pm 90 \mathrm{BP}$, marking the boundary of two shallowing sequences. The lower sequence is dated 
$7810 \pm 130 \mathrm{BP}$, indicating the age where the estuary was established in the area.

In Gernika, a marine pulsation (a possible TOB) can be deduced from the occurrence of planktonic and outer shelf and slope benthic foraminifers in the estuarine palaeoenvironments during the modern Holocene. An increase in grain size and carbonate values is also evident in these levels of the studied cores. Nevertheless, it is important to note that isolated planktonic foraminifer occurrences can also be indicative of storm water inundations. The areal influence of the flooding could have been controlled by the palaeo-topography of the estuary (Fig. 8), which caused a major marine influx in northern areas (GER 98-5), and this could explain why in inner cores (GER 98-4, GER 98-1) the deepest facies found is that of a mudflat, while in the remaining outer cores the deepest facies is a marine shelf.

Based on the chronostratigraphic framework of Figure 7, it is possible to deduce the occurrence of a pulsation dated at $1.9 \mathrm{ka} \mathrm{BP}$ that occurred at the same time as TOB T6 (Fletcher et al., 1993), and was recorded only in the outer estuary of Gernika (GER 98-5).

Since is not possible to define a world eustatic curve for the Quaternary (Stanley, 1995), we have compared our results with others from the Bay of Biscay (Mary, 1990; Pirazzoli, 1991; Cearreta and
Murray, 1996). We assume a high sea-level situation, as proposed by Pirazzoli (1991) for the French Atlantic and by Mary (1990) for the northern coast of Spain. During the Atlantic Chron (Fig. 7), the rising sea-level trend caused the estuary of Gernika to flood with all tides. The area was below the MHWNT level. At that time, the outer estuary was a marine shelf environment, while the head of the estuary was a mudflat.

Marshes in Urdaibai started to develop at about $4.6 \mathrm{ka}$, at the same time as elsewhere in the region. Sediments of the Medoc peninsula, close to the Gironde estuary mouth, were studied by Pontee $e t$ al. (1998). Theses authors concluded that the sealevel rise slowed during the 6000-4000 BP interval, producing an increase in the terrigenous sedimentation and the establishment of the first generation of marshes in the area, at the same time as this occurred in Gernika.

During the Sub-Boreal, low to middle marsh developed over the whole area. After 4.6 ka the transition from mudflat to low marsh environments occurred in the whole estuary of Gernika, except in the outer estuary (GER 98-5), where it occurred later, probably due to the outer location of this core that was directly influenced by marine waters.

Finally, during the Sub-Atlantic stadial, sedimentary filling was completed through the stabilisation

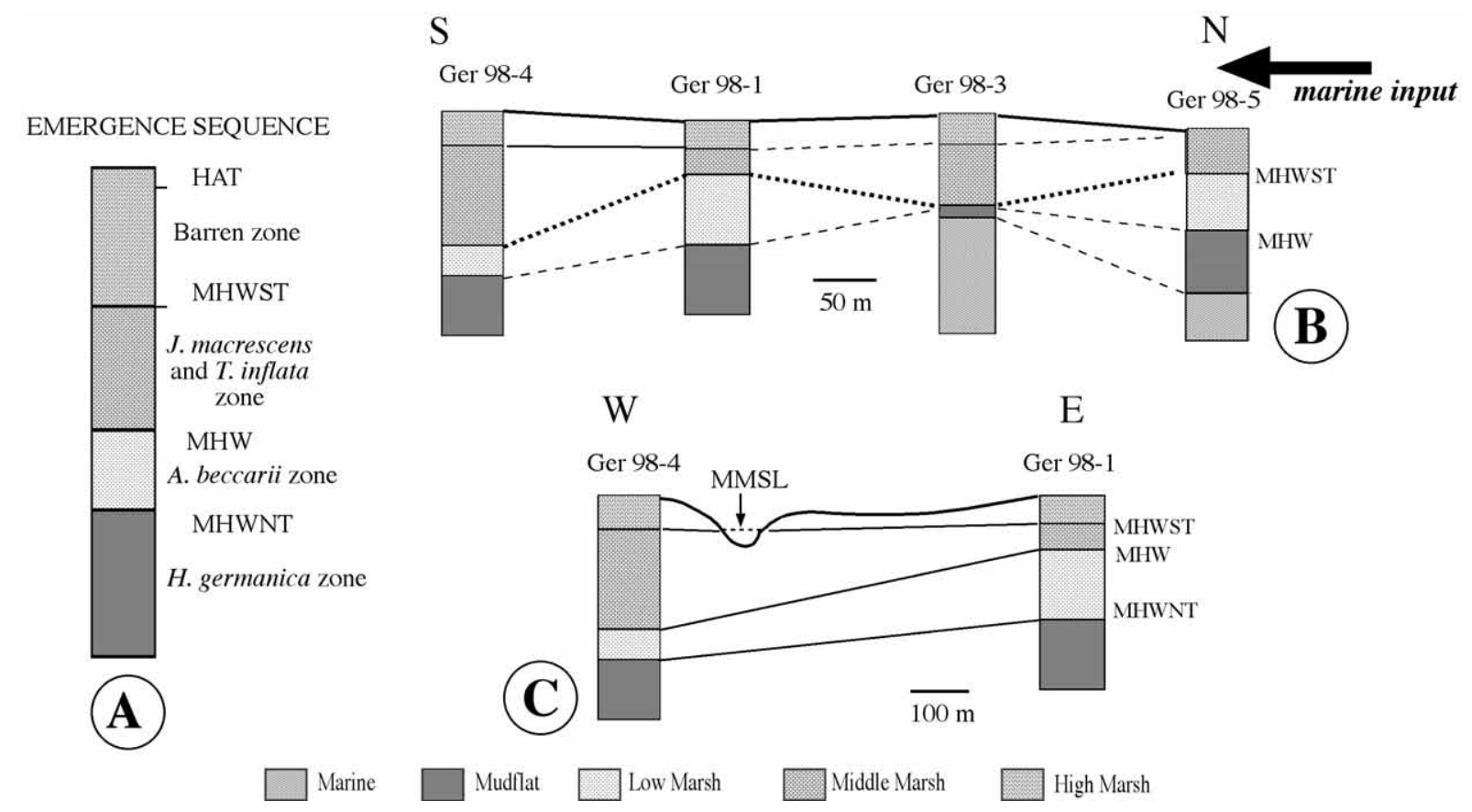

FIG. 8. - A. Foraminiferal emergence sequence model and mean tide-levels (after Haslett et al., 1998, 2001, modified). B. N-S profile in the estuary of Gernika, with modern topography, to show the marine influence from the North. C. Transversal (W-E) profile in the upper estuary, between locations of cores 98-4 and 98-1. MMSL, modern mean sea level. 
of vegetated high marshes, which were only flooded by the equinoctial tides (HAT). The outer estuary remained a middle marsh and never became higher than the MHWST level. A possible TOB has been detected in this context, at the top of the low marsh $(1910 \pm 50 \mathrm{BP})$.

A pulsation of a similar age has also been detected in other places than the southern Bay of Biscay. In the coastal lagoon of Arcachon (France), Kingebiel and Gayet (1995) described three phases in the sedimentary filling of the area. A first marine phase of 5000 to $2500 \mathrm{BP}$, a second one of transgressive tide channels with coquinas, dated 2600 to 1500 BP (Fig. 7), and a modern one of restricted mud flats. Dune fields have also been described on the Aquitaine coast, with sand composed of shelf deposits reworked during the holocene sea-level rise. Two intervals of dune activation have been dated at 3000-2300 BP and 1500-200 BP (Tastet and Pontee, 1998). In Medoc, France (Pontee et al., 1998) a sand bar was formed (Richard bar) around 2575-1420 BP that caused the isolation of marsh areas from the estuary. A second generation of marshes then started at about 1200 BP. In La Perroche (Oleron, France) the filling of marshes areas during the last 6000 years has been studied by means of the ostracod faunas by Clave et al. (2001), evidencing a transgressive event between 3500 and 2100 years BP. This event was interpreted as sealevel rise and/or coastal hydrodynamic increase. Finally in Asturias (N Spain), in the Xivares Bay, a marine pulsation dated 2250 BP was detected (Mary, 1990).

\section{CONCLUSIONS}

A detailed study of the sedimentology and foraminiferal assemblages in four cores from the estuary of Gernika (South Bay of Biscay) leads to the following conclusions:

1) The estuary was filled during the last $6.5 \mathrm{ka}$ following a general accretional model. Marshes began to develop in this area from about $4.6 \mathrm{ka}$ ago. This model, based on benthic foraminiferal zones, is described for the first time in this region. Those zones define a general emergence sequence, interrupted by eventual transgressive marine pulsations.

2) Based on benthic foraminiferal zones characteristic of modern tide-levels, a model of the changes over time in the estuarine sub-environments in this area during the modern Holocene has been proposed.

3) Detailed differential changes of the palaeoenvironments in the outer and inner estuary have been established, in relation to the mean high tide water levels of the region.

4) Benthic foraminifer zones define a general emergence sequence, interrupted by a transgressive marine pulsation dated of $1910 \pm 50 \mathrm{BP}$.

5) The middle marsh sub-environment began to develop in the outer estuary from about $1.9 \mathrm{ka}$, while in the remaining areas of the estuary a high-marsh developed, which has been cultivated since the $18^{\text {th }}$ century.

\section{ACKNOWLEDGEMENTS}

This work benefited from grants awarded by the Urdaibai PU97/8 research project, of the Department of Education, Universities and Research of the Basque Government, and PB98/0245 (DGI, Ministery of Science and Technology, Spain).

\section{REFERENCES}

Benito, I. and M. Onaindia. - 1991. Estudio de la distribución de la plantas halófilas y su relación con los factores ambientales en la marisma de Mundaka-Urdaibai. Implicaciones en la gestión del medio natural. Eusko Ikaskuntza. Cuad. Secc. Cienc. Nat., 8: 1-116.

Boomer, I. - 1998. The relationship between meiofauna (ostracoda, foraminifera) and tidal levels in modern intertidal environments of North Norfolk: a tool for palaeoenvironmental reconstruction. Bull. Geol. Soc. Norfolk, 46: 17-29.

Bosence, D.W.J. and P.A. Allison. - 1995. A review of marine palaeoenvironmental analysis from fossils. In: D.W.J. Bosence and P.A. Allison (eds.), Marine Palaeoenvironmental Analysis from Fossils. Geol. Soc. Spec. Pub., 83: 1-5.

Cearreta, A. - 1988. Distribution and ecology of benthic foraminifera in the Santoña estuary. Rev. Esp. Paleontol., 3: 23-38.

Cearreta, A. - 1989. Foraminiferal assemblages in the ria of San Vicente de la Barquera (Cantabria, Spain). Rev. Esp. Micropal., XXI (1): 67-80.

Cearreta, A. - 1992. Ecoestratigrafía (foraminíferos bentónicos) del relleno estuarino Holoceno en el litoral vasco (Golfo de Bizkaia). Riv. Ital. Paleontol. Stratigr., 98: 243-266.

Cearreta, A. - 1994. Análisis micropaleontológico e interpretación paleoecológica del relleno sedimentario holoceno en el estuario del Bidasoa (Golfo de Bizkaia). Geobios, 27: 271-283.

Cearreta, A. and J.W. Murray. - 1996. Holocene paleoenvironmental and relative sea-level changes in the Santoña Estuary, Spain. J. Foramin. Res., 26(4): 289-299.

Cearreta, A. and J.W. Murray. - 2000. AMS 14C dating of Holocene estuarine deposits: consequences of high.energy and reworked foraminifera. The Holocene, 10: 155-159.

Clave, B., P. Carbonel, L. Masse and J.P. Tastet. - 2001. Histoire du marais de La Perroche à l'Holocèce: mise en place, comblement, paléoenvironnements. VIIème Coloque Inter. d'Océan. du Golfe de Gascogne, Biarritz 2000, Éd. Ifremer. Actes de Colloques, 31: 242-249.

Fisher, R. A., A.S. Corbett and C.B. Williams. - 1943. The rela- 
tionship between the number of species and the number of individuals in a random sample of an animal population. J. Anim. Ecol., 12: 42-58.

Fletcher, C. H., J.E. Van Pelt, G.S. Brush, and J. Sherman. - 1993. Tidal wetland record of Holocene sea-level movements and climate history. Palaeogeogr. Palaeoclimatol. Palaeoecol., 102: 177-213.

Gehrels, W.R. - 1999. Middle and Late Holocene Sea-Level Changes in Eastern Maine Reconstructed from Foraminiferal Saltmarsh Stratigraphy and AMS ${ }^{14} \mathrm{C}$ Dates on Basal Peat. Quaternary Res., 52: 350-359.

Gehrels, W.R. and O. Van de Plassche. - 1999. The use of Jadammina macrescens (Brady) and Balticammina pseudomacrescens Brönnimann, Lutze and Whittaker (Protozoa: Foraminiferida) as sea-level indicators. Palaeogeogr. Palaeoclimatol. Palaeoecol, 149: 89-101.

Gobierno Vasco. - 1993. Urdaibai reserva de la Biosfera. Serv. Central Public. Gobierno Vasco, Vitoria/Gasteiz.

Haslett, S.K., P. Davies and F. Strawbridge. - 1998. Reconstructing Holocene sea-level change in the Severn Estuary and Somerset Levels: the foraminifera connection. Archaeol. Severn Estuary, 8: $29-40$.

Haslett, S.K., F. Strawbridge, N.A. Martin and C.F.C. Davies. - 2001 Vertical saltmarsh accretion and its relationship to sea-level in the Severn Estuary, U.K.: an investigation using foraminifera as tidal indicators. Est. Coast. Shelf Sci., 52: 143-153.

Hippensteel, S.P., R.E. Martin, D. Nikitina and J.E. Pizzuto. - 2000 The formation of Holocene marsh foraminiferal assemblages Middle Atlantic coast, U.S.A.: implications for Holocene sealevel change. J. Foramin. Res., 30 (4): 272-293.

Klingebiel, A. and J. Gayet. - 1995. Fluvio-lagoonal sedimentary sequences in Leyre delta and Arcachon bay, and Holocene sea level variations, along the Aquitaine coast (France). Quatern. Int., 29/30: 111-117.

Loeblich Jr., R. and H. Tappan, H. - 1988. Foraminifera genera an their classification. Van Nostrand Reinhold, New York.

Long, A. - 2000. Late Holocene sea-level change and climate. Prog. Phys. Geog., 24: 415-423.

Mary, G. - 1983. Evolución del margen costero de la Cordillera Cantábrica en Asturias desde el Mioceno. Trab. Geol. Univ. Oviedo, 13: 3-35.

Mary, G. - 1990. La evolución del litoral Cantábrico durante el Holoceno. In: A. Cearreta and F.M. Ugarte (eds.), Proc. Inter. Conf. on the Environment and the Human Society in the Western Pyrenees and the Basque Mountains during the Upper Pleistocene and the Holocene, pp. 81-87. Vitoria.

Meaza, G. and F.M. Ugarte. - 1988. La transformación del espacio natural por el agrosistema vascocantábrico. La ria de GernikaMundaka. Lurralde, 11: 137-147.

Murray, J.W. - 1973. Distribution and Ecology of Living Benthic
Foraminiferids. Heinemann, London.

Murray, J.W. - 1991. Ecology and palaeoecology of benthic foraminifera. Longman Scientific Technical, Harlow.

Pascual, A. - 1992. Utilización de los foraminíferos bentónicos para un mejor conocimiento del medio ambiente en los estuarios vizcainos (Gernika y Bilbao). Rev. Esp. Micropal, XXIV (1): 33-57.

Pascual, A., M. Pujos an X. Orue-Etxebarria. - 1991. Variations morphologiques chez Ammonia beccarii, dans la ria de Gernika (Golfe de Gascogne). Bull. IGBA, Bordeaux, 50: 93-105.

Pascual, A., J. Rodríguez-Lázaro, O. Weber and J.M. Jouanneau. 2002. Late Holocene pollution in the Gernika estuary (Southern Bay of Biscay) Evidenced by the study of Foraminifera and Ostracoda. Hydrobiologia, 475/476: 477-491.

Pascual, A., O. Weber, J. Rodríguez-Lázaro, J.M. Jouanneau and M. Pujos. - 1998. Le comblement de la ria de Gernika (golfe de Gascogne) à l'Holocène terminal. Oceanol. Acta, 21(2): 263-269.

Pirazzoli, P.A. - 1991. World atlas of Holocene sea-level changes. Elsevier, Amsterdam.

Pontee, N.I., J.P. Tastet and L. Masse. - 1998. Morpho-sedimentary evidence of Holocene coastal changes near the mouth of the Gironde and on the Medoc Peninsula, SW France. Oceanol. Acta, 21 (2): 243-261.

Pujos, M. - 1976. Ecologie des foraminifères benthiques et de thécamoebiens de la Gironde et au plateau continental SudGasconge. Application à la connaissance du Quaternaire terminal de la région Ouest-Gironde. Mém. IGBA, Bordeaux , 8: 1- 438 .

Pujos, M. - 1983. Jadammina polystoma, temoin d'un environment contraignant dans l'estuaire de La Gironde (France). In: H. Oertli (ed.), Benthos'83, Second Intern. Symp. on Benthic Foraminifera Pau, pp. 511-517.

Scott, D.B. and R.M. Leckie. - 1990. Foraminiferal zonation of great Sippewissett salt marsh (Falmouth, Massachusetts). $J$. Foramin. Res., 20: 248-266.

Scott, D.B. and F.S. Medioli. - 1986. Foraminifera as sea-level indicators. In: O. Van de Plassche (ed.), Sea-level research: a manual for the collection and evaluation of Data, pp. 435-457. Geobooks, Norwich.

Stanley, D. J. - 1995. A global sea-level curve for the late Quaternary: the impossible dream? Mar. Geol., 125: 1-6.

Tastet, J.P. and N.I. Pontee. - 1998. Morpho-chronology of coastal dunes in Médoc. A new interpretation of Holocene dunes in Southwestern France. Geomorphology, 25: 93-109.

Ters, M. - 1973. Les variations de niveau marin depuis 10000 ans, le long du littoral Atlantique française. In: Bulletin Association Française de l'étude du Quaternaire (ed), Le Quaternaire: géodynamique, stratigraphie et environnement, 9ème. Congrès Intern. de l'INOUA, supp. 36: 114-135, Christchurch, New Zealand.

Received July 12, 2002. Accepted November 24, 2004 
